\section{RHESUS PROPHYLAXIS AFTER TWIN DELIVERY}

Sir:

I should like to call the attention of your readers to the increased hazard of primary $\mathrm{Rh}_{\mathrm{o}}$ (D) isoimmunization after multiple delivery in a nonsensitized $\mathrm{Rh}$-negative patient whose progeny are Rh-positive. Under such circumstances, large amounts of fetal cells may pass into the maternal circulation and subsequently produce irreversible $R_{h_{o}}(D)$ isoimmunization (Pollack et al. I 969 ).

At present there is no agreement on the exact amount of fetal cells which pass into the maternal circulation at the time of delivery. Hughes-Jones and Mollison (1968) have suggested that it is in the magnitude of 0.1 to $0.25 \mathrm{ml}$ for single term deliveries. There is general agreement that this rarely exceeds Io $\mathrm{ml}$ for normal deliveries (Keith I972). When operative procedures such as version and extraction of the second twin or manual removal of the placenta are performed, the amount of fetal cells passing into the maternal circulation could be much greater.

While only about two-thirds of $\mathrm{Rh}$ negative individuals can be immunized to the $\mathrm{Rh}$-factor under normal circumstances, the proportion of subjects in whom serologically detectable anti-Rh is formed varies directly with the amount of red blood cells acting as the antigenic stimulus (Pollack et al. I97Ia). It has been shown that if the size of the antigenic stimulus reaches $500 \mathrm{ml}$ of $\mathrm{Rh}$-positive blood, the percentage of individuals responding with a production of antibodies can be as high as $8 \mathrm{I} \%$ (Pollack et al. I97 $b$ ). Irrespective of the size of the antigenic stimulus, the production of such antibodies could signal an end to the reproductive career of an otherwise healthy young woman.

It is quite reasonable to propose that when $R$ h-negative nonsensitized mothers deliver twins, attempts should be made to quantitate the size of the transplacental hemorrhage, since these patients appear to be in a special high-risk category. There are two ways to do this. The first is the use of the $\mathrm{D}^{\mathbf{u}}$ test read under a microscope. When carefully performed, as little as $20 \mathrm{ml}$ of fetal blood in the entire maternal circulation may be detected. At this level it is a good screening test for massive fetomaternal hemorrhages. It is, in essence, a differential agglutination test of the $\mathrm{Rh}$ positive cells. A more sensitive test for the detection of Rh-positive cells in an $\mathrm{Rh}_{\text {- }}$ negative cell population is the KleihauerBraun-Betke acid elution technique (I957) which is capable of demonstrating one fetal cell in 200,000 maternal cells. Unfortunately, this test is not always available. Ideally, the blood bank should be notified shortly prior to delivery of an Rh-negative multiple gestation to prepare for either of these tests.

If no attempts are made to quantitate the amount of anti-D immune globulin required, the patient might receive a dose which, while adequate for a normal delivery, abortion, or ectopic pregnancy, leaves her unprotected after her multiple births. Under some circumstances, insufficient dosage may even lead to enhancement of subsequent antibody formation (Pollack et al. I969).

A special problem may arise if the Rhtyping is done postpartum, and the mother has sustained a significant transplacental hemorrhage at the time of delivery. Under such circumstances, the test for the $D^{u}$ factor may be read as wealky positive by an inexperienced technician. What is actually being seen is the agglutination of the minor population of Rh-positive fetal cells present in the mother's circulation. The test thus becomes one of differential agglutination and is wrongly interpreted as indicating a positive $\mathrm{D}^{\mathbf{u}}$ factor. Since no anti-Rh therapy is given to mothers who 
are $D^{u}$ positive, many potential recipients may be excluded in this manner. To avoid this problem, Rh-typing should ideally be done antepartum.

An accepted method of anti- $\mathrm{Rh}_{0}(\mathrm{D})$ immune prophylaxis is RhoGAM®. Each vial contains no less than $300 \mu \mathrm{g}$ of anti$\mathrm{Rh}_{\mathrm{o}}(\mathrm{D})$ immune globulin, and is capable of neutralizing $\mathrm{I} 5 \mathrm{ml}$ of Rh-positive cells, since Pollack and coworkers (I97 $b$ ) have demonstrated that it requires $20 \mu \mathrm{g}$ of the immune globulin to neutralize each $\mathrm{ml}$ of packed cells.

Thus, an individual dose of anti-R $h_{0}(\mathrm{D})$ may be calculated for each patient depending on the size of the transplacental hemorrhage. Complete directions for the administration of an adequate dose of anti-Rh therapy have been outlined in the literature (Keith I972).
The use of large doses of anti-immune globulin, tailored to fit the size of the antigenic dose, is not without precedent. No ill effects have been observed when as high as $18,000 \mu \mathrm{g} / \mathrm{ml}$ have been administered (Keith et al. I970, and Keith and Hauser I97 I). In order to assess the effect of therapy, it is advised that the patient be followed for six months or more to demonstrate the disappearance of the passively administered antibody and the absence of actively produced antibody. The indirect antiglobulin test (Coombs) is not sufficiently sensitive for this task, but enzymatic or automated techniques should be used (WHO Report I97I).

Lours KerTH, M.D.

Cook County Hospital I825 West Harrison Street Chicago, Illinois 60612, USA

\section{REFERENCES}

Hughes-Jones N.C., Mollison P.L. 1968. Failure of a relatively small dose of passively administered anti-Rh to suppress primary immunization by a relatively large dose of $\mathrm{Rh}$-positive red cells. Br. Med. J., I: I50-I5I.

Keith L., Cuva A., Houser K., Webster A. 1970. Suppression of primary Rh-immunization by Anti-Rh. Transfusion, 10: 142-147.

Keith L.G., Hauser G. 1971. Anti-Rh immune globulin after a massive transfusion accident. Transfusion, II : I 72 .

Keith L. 1972. Anti-Rh therapy after transfusion. J. Reprod. Med., 8: 293-298.

Kleihauer E., Braun H., Betke K. 1957. Demonstration von fetalem Haemoglobin in den Erythrocyten eines Blutausstrichs. Klin. Wochenschr., $35: 637$.
Pollack W., Gorman J.G., Freda V.J. rg6g. Prevention of Rh-hemolytic disease. Progr. Hemat., 6: $121-147$.

Pollak W., Ascari W.Q., Kochesky R.J., O'Connor R.R., Ho T., Tripodi T. I971a. Studies in rhesus prophylaxis. I. The relationship between dose of anti-Rh and the size of the antigenic stimulus. Transfusion, I I : 333-339.

Pollack W., Ascari W.Q., Crispen J.F., O'Connor R.R., Ho T. I97I $b$. Studies on rhesus prophylaxis. II. Rh-immune prophylaxis after transfusion with Rh-positive blood. Transfusion, II: 340-344.

WHO Report 468. 1971. Prevention of Rh-sensitization: Report of a WHO Scientific Group: I-36. WHO, Geneva. 